\title{
CRITICAL ANALYSIS OF THE INCLUSIVE EDUCATION IMPLEMENTATION IN THE CONCEPT OF FREEDOM OF THE SOUL AND ZONA PROXIMAL DEVELOPMENT
}

\author{
Asri Wijiastuti \\ Jurusan Pendidikan Luar Biasa Fakultas Ilmu Pendidikan Universitas Negeri Surabaya \\ asriwijiastuti@unesa.ac.id \\ Siti Masitoh, Ima Kurrotun Ainin, Febrita Ardianingsih \\ Jurusan Pendidikan Luar Biasa Fakultas Ilmu Pendidikan Universitas Negeri Surabaya \\ sitimasitoh@unesa.ac.id, imainin@unesa.ac.id, febritaardianingsih@unesa.ac.id
}

\begin{abstract}
Abstrak
Ki Hadjar Dewantara meletakkan dasar pendidikan di Indonesia melalui pemikirannya terkait dengan sifat anak-anak pada tahun 1913-1919. Di sisi lain, Lev Vygotsky (18961934) menyatakan teori bahwa anak-anak dapat belajar dengan bantuan orang yang kompeten. Kedua teori tersebut menggambarkan bahwa implementasi pendidikan akan memberikan kebebasan dan kebahagiaan bagi anak dalam belajar belajar dengan memahami anak secara alami dan sebagaimana adanya. Penelitian yang telah dilakukan dengan menggunakan desain etnografi bertujuan untuk membedah dan melacak pemikiran Ki Hadjar Dewantara dan teori Vygotsky dalam implementasi pendidikan inklusif. Pengumpulan data dilakukan melalui studi dokumentasi, diskusi kelompok terpimpin, dan kuesioner. Hasil analisis posisi teori Vygotsky dalam penerapan pendidikan inklusif dalam konsep Zona Pengembangan Proksimal difokuskan pada bagaimana anak-anak membangun pengetahuan sesuai dengan budaya dan cara mereka. Konsep ZPD yang berfokus pada teori kognitif muncul sekitar tahun 1993 yang di Indonesia sendiri telah dikembangkan oleh Ki Hadjar Dewantara pada tahun 1913-1919 penekanannya adalah pada pengajaran sesuai dengan sifat anak. Filosofi Ki Hadjar sangat dipengaruhi oleh pemikiran Maria Montessori yang menekankan nilai kegiatan mandiri anak-anak dan pentingnya pertumbuhan anak sebagai individu. Pada tahun $1952 \mathrm{Ki}$ Hadjar Dewantara menciptakan pendekatan "sistem di antara" yang mengedepankan "Kebebasan Jiwa". Sistem yang mendukung sifat alami anak untuk mengembangkan kehidupan dalam dan luar sesuai dengan sifatnya sendiri. Pengetahuan dan kecerdasan hanyalah alat, buah adalah kematangan jiwa yang bisa mewujudkan kehidupan dan mata pencaharian secara tertib, suci, dan bermanfaat bagi orang lain. Konsep "Kebebasan Jiwa" dan ZPD, diselaraskan dalam pandangan kognitif dan upaya anak-anak dalam memperoleh konsep pengetahuan dalam implementasi pendidikan di kelas.
\end{abstract}

Kata Kunci: Pendidikan inklusif, kebebasan jiwa, ZPD, sifat pengantar anak

\begin{abstract}
Ki Hadjar Dewantara laid the foundation of education in Indonesia through his thoughts related to the nature of children in 1913-1919. On the other hand Lev Vygotsky (18961934) stated a theory that children are able to learn with the help of competent people. Both theories illustrate that the implementation of education will provide freedom and happiness for children in learning to learn by understanding children naturally and as
\end{abstract}


they are. Research that has been done using ethnographic design aims to dissect and trace Ki Hadjar Dewantara's thoughts and Vygotsky's theory in the implementation of inclusive education. Data collection is done through documentation studies, guided group discussions, and questionnaires. The results of the analysis of the position of Vygotsky's theory in the implementation of inclusive education in the concept of the Zone of Proximal Development are focused on how children construct knowledge according to their culture and ways. The ZPD concept which focuses on cognitive theory emerged around 1993 which in Indonesia itself had been developed by Ki Hadjar Dewantara in 1913-1919 the emphasis was on teaching according to the nature of the child. Ki Hadjar's philosophy is heavily influenced by Maria Montessori's thoughts which emphasize the value of children's independent activities and the importance of children's growth as individuals. In $1952 \mathrm{Ki}$ Hadjar Dewantara created a "system among" approach that put forward "Freedom of the Soul". The system that supports the child's natural nature in order to develop inner and outer life according to his own nature. Knowledge and intelligence are only tools, the fruit is the maturity of the soul that can realize life and livelihood in an orderly, holy, and useful for others. The concepts of "Freedom of the Soul" and ZPD, are aligned in the cognitive view and efforts of children in obtaining the concept of knowledge in the implementation of education in the classroom.

Keywords: Inclusive education, Freedom of the soul, ZPD, nature of child Introduction

\section{INTRODUCTION}

Teacher perceptions related to the implementation of inclusive education according to research results of Rohman (2017); Sulistyaningsih (2017); Fajrillah (2018); and Amka (2019) still means that children with disabilities learn together in one class with regular children. Looking at the results of the study it was found that the concept of implementing inclusive education still varied, some using a pull-out or full time service system in the same class, as well as being related to the curriculum used, it also varied. This condition implies the importance of conducting critical analysis related to children whose nature as humans and creatures that can be educated (animal educable) and must be educated (animal educandum) in an effort to perceive the concept of inclusive education according to the theoretical basis. Ki Hadjar Dewantara with his thoughts related to children in the context of learning and inclusive is still very relevant to be studied and explored to obtain the true meaning of meaning. One of the systems approaches that was initiated by Ki Hadjar Dewantara emphasizes the freedom of children to learn and construct their knowledge acquisition according to the nature of the child. The nature of children in Ki Hadjar Dewantara's thoughts does not distinguish whether children are disabled or not, children are children. According to the results of Wardani's study (2011) educating children according to their natural nature and understanding teaching in Tamansiswa is to educate children to become human beings capable of achieving the soul freedom, mind, and energy. This is 
in accordance with the results of the thinking of Sudarto (2008) that a teacher in the thought of Ki Hadjar Dewantara is not a ruler of a child's soul but a child servant in this case as a student servant. Look at the Minister of Education's speech at the commemoration of National Teacher's Day which states "You know that every child has different needs but uniformity has outperformed diversity". The statement requires that children in inclusive education mean schools must accommodate all children regardless of physical, intellectual, social-emotional, linguistic or other conditions. This should include children with disabilities and gifted children, street children and working children, children from remote areas, or who are mobile, children from ethnic minorities, linguistics or culture and children from disadvantaged or marginalized areas or groups (Salamanca , 1994). Another opinion states that inclusive education is the placement of children with mild, moderate and severe disabilities in full class (Staub and Peck, 1995). These two opinions actually provide us with an understanding that inclusive education is an effort to provide opportunities for all (regular children and children with special needs) in obtaining education. With the diverse types of children with special needs, it means that there will also be a diverse composition of students in inclusive classes. Referring to another sentence in the Minister of Education's speech was "I will not make empty promises to you. Change is difficult and full of inconvenience. One thing is for sure I will fight for the independence of learning Indonesia ". The statement is very closely related to the concept of inclusive education which prioritizes the freedom and freedom of the soul of children in learning in accordance with nature. Concepts based on Ki Hadjar Dewantara's thoughts and Vygotsky's Zone Proximal Development (ZPD) theory are related to the existence of children with special needs in the regular classroom. ZPD in this case sees children according to their knowledge and potential knowledge, also sees children in collaborating what is currently done with what is to come. The question is what and how is Vygotsky's concept of thought related to ZPD theory in the implementation of inclusive education? Referring to the results of previous theoretical studies and relevant research in the efforts to implement inclusive education in Indonesia, there are not many analytic studies or research findings that question the Grand Theory underlying the implementation of inclusive education. This question is very intriguing to be followed up through research. Greenspan (1998) revealed that to enable children to learn to interact, it is very important to blend children with special needs with other children who are not problematic. Another theory states that once upon a time children with special needs should learn together with normal children, in order to be able to interact socially (Vygotsky, 2007). These two opinions seem to have almost the same meaning, but actually there are differences in meaning. Related to the concept of implementing inclusive education, it is suspected that Vygotsky's theory which is the foundation of philosophy and science as well as local wisdom as initiated by Ki Hadjar Dewantara has not been studied in depth in the research corridor. 


\section{METHODS}

Research on the concept of inclusive education is based on critical analysis of Ki Hadjar Dewantara's teaching values and Vygotsky's theory, using a qualitative research approach of ethnographic design. This ethnographic research used data collection methods (1) Study documents of Ki Hadjar Dewantara's values and Vygotsky's theory written by Vygotsky and his adherents related to the concept of implementing inclusive education, (2) focus group discussions (FGD) to analyze between theory and implementation inclusive education in accordance with the values taught and written by Ki Hadjar Dewantara and Vygotsky's Theory, (3) Questionnaire to teachers, and policy makers related to understanding Ki Hadjar Dewantara's paradigm and Vygotsky's theory in the implementation of inclusive education. The research subjects consisted of (1) teachers, (2) inclusive school principals and (3) policy makers related to the implementation of inclusive education. The data analysis technique uses the analysis technique of Miles and Hubermen (2012). Valid and credible data checking, in this study using data validity techniques by conducting: (1) Triangulation of methods, namely checking the degree of trust in research findings from data collection techniques through document, FGD and questionnaire methods, (2) Triangulation of sources, in this case field findings, checking the correctness of the data by comparing information, the researcher controlled again by checking the truth of the research findings to several respondents. Data confirmation can be made to teachers, principals or policy makers as providers of inclusive education, (3) Triangulation of theory is used in connection with research findings with the withdrawal of premises based on relevant theories. In this study referring to the proof of the problem formulation with the research findings.

\section{FINDING AND DISCUSSION}

\section{The Results of an Analytical Study of the Implementation of Inclusive Education in the Concept Of "Freedom of the soul" Ki Hadjar Dewantara}

Departing from socio-cultural thinking and local wisdom related to the meaning of the concept and implementation of inclusive education in Indonesia, the team agreed to explore oral and written information on Ki Hadjar Dewantara's educational philosophy. Ki Hadjar's philosophy, which is implemented in the world of teaching contained in the "Teachings of Student Affairs" is still preserved and becomes a main thing that must be mastered by lecturers, students and teachers who are in the student park education environment. In the presentation which will be elaborated from the results of observations and interviews related to the position of Vygotsky's theory in the implementation of inclusive education as follows. 
Ki Hadjar Dewantara's view of disability in the context of inclusive education

\section{a. Observation results}

Observations carried out in the Ki Hadjar Dewantara Museum on August 26, 2019. Ki Hadjar Dewantara Museum located on Jalan Tamansiswa 31 Yogyakarta, inaugurated on May 2, 1970 is a learning location that provides a long history of the growth of education in Indonesia. Inclusive teaching findings in the main hall area of the museum are lined up with a portrait of Maria Monttessori with her written philosophy that reads "Educate Children according to their Nature" and Rabindranath Tagore which colors Ki Hadjar Dewantara's views and philosophy in teaching and education. Ki Hadjar Dewantara put up a picture of the two leaders with the reason that both he considered as a new guide. Montessori and Tagore are dismantlers of the old world of education as well as the construction of new streams, streams that are in line with Indonesia, namely the national-cultural flow. Ki Hadjar is interested in Dr.'s new educational approach Maria Montessori (1870-1952) who emphasized the value of children's independent activities and the importance of children's growth as individuals. Montessori marks the growth of children with indicators towards independence as a continuing release to reach a new, greater space to adapt. In addition, Ki Hadjar was also interested in the work of Rabindranath Tagore (1861-1941), especially about the theory of education that was developed contrary to the ideas of "Western" education. Tagore visited Java and the Taman Siswa in August 1927 and was greeted with a "panembrama" sing by children accompanied by gamelan which was also played by children. He was impressed and sat on the terrace. Tagore stated that Tamansiswa have the same basis as Shanti Niketan, which are both culturally based. In the context of the meaning of inclusive education, Ki Hadjar Dewantara's philosophy which reads "Among Tamansiswa Systems" is displayed on the outside walls and museums. The among system explicitly and explicitly teaches how in teaching an educator is obliged to understand the character and capacities of children as natural in nature and provide freedom of soul to achieve independent living. The among system is a method of original Indonesian findings and formulations sourced from local wisdom and Indonesian culture. Among Ki Hadjar Dewantara's system is an appropriate method for education because it is a teaching and education method that is based on care, dedication and care (care and dedication based on love). Among systems, namely supporting the natural nature of children, so they can develop life physically and mentally according to their own nature. Knowledge, intelligence should not be used as a goal but merely a tool. The fruits of education are the maturity of the soul, which can bring about life and livelihood that is orderly, holy and beneficial to others. Fatwa which strongly supports the implementation of inclusive education is a document written "Children live and grow according 
to their own nature, education can only nurture and guide the growth of that nature. $\mathrm{Ki}$ Soeratman, et al (2011: 14) state that education according to Ki Hadjar Dewantara is an effort to advance the growth of character, mind, and body of children in the framework of the perfection of life and harmony with their world. Taufik (2016) found that the implementation of the among systems with the motto of Tutwuri Handayani is the goal, pedagogic, and educational content in accordance with the nature of nature using the method of Momong, among, and Ngemong.

\section{b. Interview results}

The results of the informal interview were conducted with a museum guide who informed that Ki Hadjar Dewantara together with Nyi Hadjar was determined to guard and care for Nyi Asti wholeheartedly and in accordance with his nature. Findings from the interviews also obtained data that Ki Hadjar's struggle to remain consistent in the world of education was supported by Nyi Hadjar (Ny Sutartinah). With subtle words according to his personality she states:

"The warriors on the front lines could have fallen one after another as heroes, the battlefield could also be a mess, but as long as Tamansiswa as the source of Candra birawa's values was still upright, the warriors of the freedom fighters would continue to be born, die one growing one thousand, and the front will be reorganized. Please if Ki Hadjar wants to jump back into the party arena, but I will not participate. I will stay here and work hard to raise Tamansiswa ". The results of this interview illustrate that the importance of education with the principle of servitude is a concept of implementing inclusive education that refers to learning according to the potential and characteristics of children without the element of coercion. This is in line with what was written by Mujiono (2019) which illustrates that the family is the first place for the education of a person. The school is a place for curricular, and extra-curricular education. Society is a place of education with a variety of functions. The system of family based and educational equality is applied in three centers communication.

\section{The Results of an Analytical Study of Vygotsky's Theory Related to the Zone of Proximal Development in The Context of The Concept of Implementing Inclusive Education}

There are two important concepts in Vygotsky's theory, namely the Zone of Proximal Development (ZPD) and scaffolding. According to the view of social constructivism, that knowledge is obtained individually by constructing its own knowledge from the process of interaction with the objects it faces and social experience. Communication is the main key to teaching with a sociocultural approach and to understand students. Understanding the character and capacity of students with disabilities is very important for educators to develop the concept of knowledge individually in accordance with the obstacles experienced by children with special needs. According to Cahyono (2010) which states that ZPD is the ability to solve problems independently and the ability to solve problems with the help of adults or colleagues who are 
more capable. The implementation of Vygotsky's thinking to learn knowledge in inclusive school settings will be able to foster understanding of children with special needs in connecting new thinking and language in constructing knowledge. The position of ZPD implementation of an educator in students with special needs is to help them understand the concept of knowledge in accordance with the capacity and language abilities of students. While scaffolding provided by educators will be able to provide a continuous understanding of concepts in social life and will be able to foster cultural values and national character in students with special needs. There are quite a number of perspectives from Vygotsky's theoretical and methodological approach regarding parenting, education, and evaluation in children with special needs. Vygotsky's ZPD and social construction, the concept of guiding activities and new psychological formulas related to age, dynamics, and socio-culture in disability, which also included ideas about the structural complexity of disability and the resource approach to disability. How can detention of disability as a socio-cultural development be achieved? Vygotsky's theory focuses on the dynamic nature of disability is important in the special didactic aspects that take into account the constant changes in the structure and content of the disability development process that is influenced by education and remedial (Gindis, 2003: 204).

There are two important concepts in Vygotsky's theory, namely the Zone of Proximal Development (ZPD) and scaffolding. According to the view of social constructivism, that knowledge is obtained individually by constructing its own knowledge from the process of interaction with the objects it faces and social experience. Communication is the main key to teaching with a sociocultural approach and to understand students. Understanding the character and capacity of students with disabilities is very important for educators to develop the concept of knowledge individually in accordance with the obstacles experienced by children with special needs. The implementation of Vygotsky's thinking to learn knowledge in inclusive school settings will be able to foster understanding of children with special needs in connecting new thinking and language in constructing knowledge. The position of ZPD implementation of an educator in $\mathrm{ABK}$ students is to help them understand the concept of knowledge in accordance with the capacity and language abilities of students. While scaffolding provided by educators will be able to provide a continuous understanding of concepts in social life and will be able to foster cultural values and national character in ABK students. In his presentation of the analysis of Vygotsky's theory on disability, it will be examined on disontogenesis and socio-cultural theories that are appropriate for the implementation of inclusive education. There are quite a number of perspectives from Vygotsky's theoretical and methodological approach regarding parenting, education, and evaluation in children with special needs. The core of social 
constructivist views on learning and development of disontogenesis: Vygotsky's developmental approach to ZPD and social construction, the concept of guiding activities and psychological new formulas related to age, dynamics, and socio-culture in disability, which also includes ideas about the structural complexity of disability and approaches resources on disability. How can detention of disability as a socio-cultural development be achieved? Vygotsky's theory focuses on the dynamic nature of disability is important in the special didactic aspects that take into account the constant changes in the structure and content of the disability development process that is influenced by education and remedial (Gindis, 2003: 204). Parents and educators feel sorry that they continue to provide assistance, so that children with special needs become helpless, and this will hamper ZPD which will result in secondary disability. Excessive oversight, various restrictions, long-term deprivation of independence as important factors causing secondary socio-cultural disability among children with special needs and intellectual disabilities (Rodina, 2005). The description of the implementation of inclusive education was examined from the results of the discussion groups led by lecturers, students, and students at Sarjanawiyata Tamansiswa University Yogyakarta on October 26, 2019 and the Principal, Teacher Supporting Children with Special Needs, and UPTD Surabaya, Gresik, Majakerto on November 4, 2019.

The results of the discussion illustrate that the implementation of inclusive education is integrated into the curriculum as well as linking with multiculturalism, equality, ZPD, among, nature of children, freedom of life, scaffolding and dysontogenesis in the main subjects always and often is done even though new meanings are understood when FGD. The teacher as a guide in the implementation of inclusive education becomes very important to understand and study more closely related to the potential and characteristics of children to be able to provide assistance in constructing concepts in children's cognitive development. ZPD in the context of implementing inclusive education provides a number of assistance without coercion to children in accordance with their true potential. Children think according to their culture and their own way. They certainly do not internalize what they see and hear in a social context. ZPD is a zone / distance above the child's actual level of development characterized by the ability to solve problems independently with the highest level of potential abilities of children characterized by solving problems with the help of others: teachers, peers or competent adults (Moll, 1994). This is supported by Yan-bin (2009) thats Lev Vygotsky thinks the Zone of Proximal Development can illustrate the function of procession not matured yet being towards maturity. Therefore, the view of mental development in the Zone of Proximal Development is foresighted, while the view of the level of real development is backdated. 


\section{CONCLUSION}

1. Learning approach in the context of "Freedom of the Soul" thought of Ki Hadjar Dewantara in the implementation of inclusive education as an effort to support the child's natural nature, so that he can develop life physically and mentally according to his own nature. Knowledge, intelligence should not be used as a goal but merely a tool. The fruits of education are the maturity of the soul, which can bring about life and livelihood that is orderly, holy and beneficial to others. One approach to the "among systems" in the motto of Tutwuri Handayani is the purpose, pedagogy, and educational content in accordance with the nature of nature using the method of Momong, among, and Ngemong that prioritizes the child's will.

2. Foundation Philosophy of freedom of learning according to the child's self-potential in scientific characteristics of the substance of the Vygotsky's theory of the Zone of Proximal Development (ZPD) in the implementation of inclusive education which further describes teachers as mentors providing assistance to children thinking according to their culture and their own ways

\section{REFFERENCES}

Amka.2019.Inclusive education for special needs students in South Kalimantan.Jurnal Pendidikan dan Kebudayaan, Vol.4, nomor 1, Juni 2019

Cahyono, Adi Nur.2010.Vygotskian Perspective: Proses Scaffolding untuk mencapai Zone of Proximal Development (ZPD) Peserta Didik dalam Pembelajaran Matematika. UNY: Seminar Jurusan Pendidikan Matematika.www.google.com diakses pada 02 November 2019

Creswell, J. W. (2013). Qualitative Inquiry \& Research Design: Choosing Among Five Aproaches, Third Edition. London: Sage Publication.

Dewantara. Ki Hadjar. (1977). Karya Ki Hadjar Dewantara bagian pertama: pendidikan. Yogyakarta: Majelis Luhur Persatuan Tamansiswa.

Direktorat PLB Ditjen Dikdasmen Depdiknas. (2003). Pedoman penyelenggaraan pendidikan terpadu/inklusi: Buku 1 Mengenal pendidikan terpadu/inklusi. Jakarta: Depdiknas.

Fajrillah, Mashadi, Zakiah, Nurjasmi, Miftahul Jannah.2018. Persepsi Guru Terhadap Pelaksanaan Pendidikan Inklusi di Pidie Jaya Jurnal Geuthèë: Penelitian Multidisiplin, Vol.01, No. 01

Gindis.B. (1999). Vygotsky's Vision: Reshaping the practice of Spcecial education for the 21 st Century. Remedial and Special Education Journal. Vol.20.No.6.pp.32-64

Gindis, B. (1994). Vygotsky's Defectology (book review on: "The Fundamentals of Defectology: Abnormal Psychology and Learning Disability"). American Journal on Mental Retardation, Vol. 100,\#2, pp. 214-216 
Milles, M. B \& Huberman, A. M. (2012) Quality Data Analysis: A. Source Book of New Method. London: Sage Publication.

Moleong, L. J. 1994. Metodologi Penelitian Kualitatif. Bandung: PT Remaja Rosdakarya.

Moll, I,C., 1994. Vygotsky and Education: Instructinal Implications and Aplications of Sociohistorical Psychology. Cambrige: University Press

Mujiono.2019. Implementasi sistem among pada pembelajaran matematika untuk membangun karakter dan kemampuan memecahkan masalah siswa.Tesis. Yogyakarta: UST

Rodina, Katarina A.2005. Vygotsky`s Social Constructionist View on Disability:

A Methodology for Inclusive Education, Desertasi. Department of Special Needs education, University of Oslo, Norway.

Rohman, Miftakhur \& Mukhibat.2017.Internalisasi nilai-nilai soiso-kultural berbasis etno religi di MAN Yogyakarta III.Jurnal Pendidikan Islam Vol.12 No. 1.2017

Rohidi R.T. 1992. Analisis Data Kualitatif. Jakarta: Universitas Indonesia.

Sulistyaningsih, ratri Yovita.2017.Survei penyelenggaraan sekolah dasar Inklusi di wilayah Yogyakarta.skripsi.Yogyakarta: UST

Salanmanca statement.1994. On principles, policy and practice in special needs education.

Staub, D., Peck, C.I,.1995. What are the outcames for nondsability students?. Educational leadership Journal of the Department of Supervision and Curriculum Development, NEA. Retrieved from : https://www.researchgate. net/publication/234608288

Tarmansyah. 2007. Inklusi Pendidikan Untuk Semua. Jakarta:Depdiknas

Taufik, Gopar.2016.Penerapan Pendekatan sistem amongpada matapelajaran gambar teknik di SMK Tamansiswa Yogyakarta.skripsi.Yogyakarta: UNY

Peraturan Menteri Pendidikan Nasional Republik Indonesia Nomor 70 Tahun 2009 tentang Pendidikan Inklusif Bagi Peserta Didik yang Memiliki Kelainan dan Memiliki Potensi Kecerdasan dan/atau Bakat Istimewa

Undang-Undang Republik Indonesia Nomor 20 Tahun 2003 tentang Sistem Pendidikan Nasoinal. (2003). Bandung: Citra Umbara

Vygotsky, L. S., 2007. Development of Children and the Process of Learning, Cambridge. MA: Harvard University Press, terj. Yogyakarata: Pustaka Pelajar

Wardani, Kristi.2011.Guru dan pendidikan karakter (Konsep Ki Hadjar Dewantara dan relevansinya saat ini). Diakses di www.google.com pada 15 Februari 2020

Yan-bin, Wang.(2009).Impact of Lev Vygotsky on Special Education.Canadian Social Science ISSN 1712-8056 Vol.5 No.5 2009 